\title{
JOURNEY FROM CLASSROOM TO WORKPLACE - ONE STUDENT'S STORY
}

\author{
Swathi Venugopal, Zeenath Reza Khan
}

\begin{abstract}
This paper uses narrative writing to track the journey of one student's perceptions and understanding of academic integrity values through practice immersion and experiences and how that is carried into the workplace. Literature has posited that narratives offer increased comprehension, interest and engagement (Dahlstrom, 2014). The paper uses storytelling as a unique methodology to capture the student's perceptions and emotions and provides a fascinating insight into the kind of experiences that shape students' understanding of academic integrity values, thus posing as valuable contributions for academics and research globally.
\end{abstract}

Key words: Academic Integrity, Contract Cheating, Plagiarism, Workplace Ethics

\section{Introduction}

Integrity in the current world has been recognized as a character that must be inculcated within students from school age. It has been included as a part of the character building strategy in schools as they direct their attention to ethics in curriculum (McCabe et al., 2006). Technological advancements have made data and knowledge sharing easier than ever before which has also drastically increased academic misconduct. Reasons ranging from passing a simple test to landing in a desired position in the highly competitive job market have been quoted as the reasons for indulging in such unfair means (McCabe et al., 2001). This has posed a challenge for various academic personnel such as educators, researchers and librarians - the necessity to control academic dishonesty incidents with students. The rise of every new challenge in this expedition has driven academic experts to experiment various pedagogical approaches to steer students away from cheating (Chao et al., 2009). However, the effect of such approaches may go unnoticed or undermined when they are not measured effectively. Measuring an output, therefore, must include all the entities that have been involved in the procedure. Who other than students themselves would be the best scale of measurement - the ones to whom academic integrity is being taught to or at least pointed to.

However, few studies have been successful in capturing student perception, other than quantitative results. This study attempts to use a novel story telling method in the form of a case study of one student's journey and experience to provide in-depth insights on factors that enable students' likelihood to cheat and factors that help shape moral decision making in students.

\section{Background}

Brinkworth (2009) highlighted the importance of student experiences wherein despite many efforts to bridge the gap between the transition from school to university, about 
$60 \%$ of students felt inadequate followed by 'reality shock' with the onset of their first semester. This has led researchers to dig deeper into understanding student perceptions, perspectives and gain better understanding between the teacher - student interaction. Very few studies have been able to examine actual student perspectives when new modules have been introduced to realize the impact of those courses. Even as early as 1984, Robert Pace noted the 'missing element' in understanding the efficacy of higher education among students; there was a pressing need for a systematic, large scale measurement of student experiences that can shape their college journey. In the past decade, there have been many studies regarding academic misconduct mitigation, teaching methods and plagiarism detection tools. However, McCabe's surveys have shown that $95 \%$ of students have admitted to engaging in some form of cheating (ICAI, 2020). Another student survey conducted in an American school reported about $65 \%$ of its students confessed to cheating, while an alarming $85 \%$ have admitted to seeing a fellow student cheat (Danilyuk, 2020). With no intention of demeaning the efforts of academic integrity experts today, sadly, there still exists a clear discrepancy in their efforts to bridge the ethical gap and seemingly preconceived notions that exist about academic integrity. Both literature and facts clarify an important truth - cheating episodes amongst students have not decreased and academic experts need to address this seriously today more than ever before. Thus, examining a student as an individual can help educators to consider microscopic details about their academic integrity journey which may not be underscored when they are studied as a population. There are barely any studies that record the grass root reality that students encounter.

The objective of this paper, therefore, is to capture one student's experience and bring the thoughts, notions and adaptation of the student to the foreground for researchers to learn and adapt their research endeavors.

\section{Methodology}

As outlined in the beginning of this paper, a storytelling methodology has been adopted by choice to delve deeper into the real life experience of one Asian female student and her encounter with academic integrity values. Understanding a student's emotional cycle and the thought process behind a student's attitude to academic integrity was a revelation into their perspective.

In a study by David Kolb (1981), he highlighted the importance for educators to understand academic disciplines from a learner's viewpoint to address barriers that were involved in their choice of an academic discipline for higher education. Typically, this would include a student's thought process that could vary based on individual cognitive development as portrayed by William Perry (1970) in his theory of Cognitive Development. In this regard, case studies and analysis of contexts has been long critiqued in the research arena for higher education. Corcoran et al. (2004) have noted that the case study approach "allows the researcher to 'go deep' and learn what works and what does not". It can help a researcher define the various complexity of factors by contextual analysis and description. Generally, case studies embark on the journey and find the answers to "how" and "why" a situation arises as it did. For academic integrity, this facet of case studies may be critical in perceiving the role of academic 
integrity in cognitive development which is critical to the student's orientation towards learning and their long term success (Markwell, and Courtney, 2006) If a case study is well-validated and defines interaction of all factors present in a system thoroughly, it can transform the course of research and yield rich results, just like any quantitative research methodology does. While researchers do understand that case studies should not always follow the generalization route by upholding one case's analysis as a template or verdict, building a database of good case studies can improve the final outcome of a research objective by its repeatability and transparency. There have been many studies being conducted on academic integrity on a quantitative basis to understand students as a population. However, there exists a definite need to understand the thoughts and emotions involved from an individual student's perspective (ComasForgas, and Sureda-Negre, 2010)

Correlating to this approach, narration and storytelling can explore various intricate details within human character with a window into the lives of those who experience a phenomenon (Solórzano, and Yosso, 2002). Stories have been a part of the fundamental unit of building societies as they share thoughts, experiences and structures amongst people to elicit emotion. It can help both hearers and speakers to separate positive models from negative models by providing vital support in problem solving amongst all participants of a story (Jonassen, and Hernandez-Serrano, 2002) This case study uses such methodology seeking to identify, verify and rectify the essence behind the characters involved in the case study.

\section{Case study}

\section{Case background}

The story is that of an Asian female who graduated with a bachelor degree in Business and Commerce from a western university and is currently employed. Before that, she graduated from an Asian schooling system. She began working as a research assistant to a faculty whose primary area of research was academic integrity. During her tenure working on literature, conducting background studies, and helping with organizing the International Day of Actions Against Contract Cheating and a conference on integrity on campus, she began her journey reflecting on integrity as a value, how and when it was introduced to students and how it impacted her at class, work and life.

This is her story.

\section{My journey from classroom to workplace}

"Do not be misled... Whatever a person is sowing, this he will also reap." - Galatians 6:7.

If life can be likened to a fruit - integrity would be its seed. The seed in most fruits is covered by the fruit pulp, only to be discovered after we consume the fruit. It may not be visible, but it is the core and can grow to life. Integrity is the core of a person's character, his intentions and deeds. Integrity can determine authenticity, trustworthiness and dependency of a person. Yet, it is not deemed as a 'practical' or a 'cool' concept. In my 
life, I learnt the words of Galatians 6:7 by heart early on, but understood the importance of it much later.

Right from primary school, I loved to learn at school. I loved so many of my teachers and still remember them in nostalgia. My learning was sometimes determined by my love for the subject or the teacher who taught me. To the extent, if my mother taught me something at home, I wouldn't really listen but if my teacher told the same thing, I wouldn't think twice. Amongst the subjects I loved was Moral Science. It was an exclusive subject taught in Indian Schools and had a final exam. It was easy to score and had value based stories that students loved. But no teacher or moral science topic taught me integrity. It was not even a concept for consideration.

In my wits, the first time I bumped on integrity was on an exam paper that said: "Zero marks will be awarded for students who engage in unfair means and the paper will be cancelled."

So cheating or compromising your integrity was a self-understood value. The reasoning would be:

"Cheating is wrong and if you do so, you will be punished."

There was always an underlying fear of being caught cheating if you had the courage to do so.

As I progressed to middle and secondary school, subjects became more difficult to cover and understand.

From a society that judges based on marks, high net worth students are the ones that score the highest marks. With time, pressure only increased stress levels for students and parents in a race for the top rank. No matter how hard one would study, there were so many factors that determine your marks in the subject such as:

- understanding from the teacher who taught that subject,

- the teacher who sets the paper,

- the teacher who would examine answer sheet (not necessarily the one who taught would examine the paper always),

- the private tuition teacher who taught the same concept, and

- student stress management capabilities.

If you notice, none of the above factors are related to real time learning - they are related to scoring of marks in an exam.

As students, all we were worried about were - marks.

At one tipping point, we students gave up studying for exam. The pressure turned into courage - to do the wrong, to cheat. If one could spend time, think of 'sharing' strategies - marks would flow automatically. Factors that determined how well one could cheat were:

- the subject,

- your friendship with the smartest kid,

- the seating of your best friend,

- the type of 'strategy', and

- the invigilator in the exam hall. 
After all, sharing is caring and students cared about their marks, the smile of approval from their parents and of course their student net worth. No student was in a position to think of real and long term consequences of such measures and neither was I.

Secondary school 'sharing' can also have a different purpose. It may not even be considered for marks but to be 'cool'. It was a 'cool' act and labelled you 'courageous'. Often instigated by the popular students who did not have 'time' to study - this was an opportunity not to be missed if you wanted to be a part of the gang. Finding different ways to cheat was cool, executing the plan was even cooler. 'Dodging the invigilator and sending signals on which answer you want' sent an adrenaline rush through teenage spines. I am not an angel; I did try it out.

I hated Physics - I still do. But I loved it once because my teacher Miss X made it practical and enjoyable. But her tests were tough or so we thought. So once when I did not study enough, I decided to try it out. The gang was there, my best friend was there and they all had a plan. It was too good to miss and I had to prove my mettle to be a gang member too. The test day arrived and we all executed it with ease. I remember the feeling of accomplishment I had - Miss X did not find out. Next Physics class was the climax, she was going to handover our test results and we were anxiously waiting. I still remember the scene: Miss X walked into the class, we wished her and for a good five minutes only kept the papers down and looked at us in silence. Anxiety was at its peak because her face suggested that we had fared badly in the test - until she uttered those terrifying words. "I know what happened - Your papers are too similar. I will give you until next class to own up."

All the gang members gazed quick looks at each other. Little did I realize then, I had not done badly in a test - I fared badly in life. After so much thinking, I went alone and owned up my mistake even though I knew I was going to be reported on.

But Miss X did the unbelievable - she didn't report to anyone. I heard there were others who owned up for some reason, but she did not say one name. Miss X did not use the fear route, her action taught us the value of actions. All she told me was: "don't do this next time - you will go nowhere in life."

Believe it or not, that was the last time I ever did so. Cheating did not take me anywhere that time and I realized there was nothing 'cool' about it. If one facet of integrity was refraining from cheating at school - I had learnt my lesson.

University came with its own challenges of a new environment and new subjects but that episode was unforgettable to every last detail. Essay mills and vendors were available with assignments to 'purchase' from but it was not a long term solution. I could 'purchase' an assignment but who would do my assignments later in life?

It was in university where I was introduced to academic integrity as the name of this entire proposition and realized it was the need of the hour than ever before.

But integrity did not stop at university too.

As a young graduate eagerly waiting to carve her niche in the corporate world, landing into a job was the next step. I was accepted into a startup digital agency that was dealing with digital marketing solutions. I was appointed as a Coordinator and Writer for websites and social media. It was a challenging role for me with its own temptations. I had to be on my toes, attending to client's requirements and multi-task. 
Writing being one of those tasks, was often deemed the easier of the lot. Other writers were at constant pressure of completing their writing deadlines. I was not an exception; pressure did get to me, though.

In an effort to help me out, my management suggested that I take some content from the internet. I was quite surprised that they were ready to copy and paste it from an unknown website, change a couple of words just enough to escape from text matching websites. The work was comparatively menial, so they felt this would save a lot of time for me. But what they didn't realize was this - even if the client was not really going to check the authenticity of the content, there was a sense of trust involved. Although they never pressured me, I must admit that as tempting as it got, I was not going to do it. This was because there is an image of the company I was working with and I did not want it to be tarnished.

There were times when they felt I was a little extreme, but in the end when the client lauded the work, they too felt I had a point. To me copied content was like stealing if I did not reference my work; and it was not going to define another company's work.

Integrity took a new turn and it was the ultimate peak at work. What often amazes me in this ordeal is how they treated plagiarism - the fact that everyone knows shoplifting is wrong but not 'Netlifting' content or someone's work still boggles me. Principally, they knew that it was wrong but it was not practical enough to go the extra mile.

So does that mean one can steal from a grocer if it was 'practical' and if no one was watching? As ironic as it sounds, it is the attitude that plays an important role in determining integrity at work places.

As the saying goes, “you don't make a mistake twice, the second time you do, it's a choice". So is integrity a choice in today's world. I learned that if you are aware of integrity values, you can't make a mistake the second time. It starts from within - the attitude. And just like respect, don't expect integrity from the opposite side if you don't give it. I have learned to demonstrate integrity in my practice and expect it back. If you are denied it, demand it because the world needs it.

In the end, I believe a variety of experiences shape how we understand integrity values, particularly in the academic arena. One teacher changed my outlook. But how many students are fortunate in this curriculum?

If a student is introduced to integrity values for the first time in the university, is our education system really preparing honest, fair, trustworthy, courageous, respectful and responsible individuals? It does not stop at school, it carries deeper consequences into the workplace and beyond and I hope my story provides the insight to teachers and decision makers to realize the importance of making an active effort to introduce integrity to students at a young age.

\section{Inferences and Implications for educators}

Educators today are exploring various teaching methods to reach student minds with academic concepts that form a part of their knowledge acquisition. However, the story above does not suggest that a student can welcome plagiarism so easily, just like an 
academic concept. There exists an interplay of factors that affect a student who resorts to cheating and plagiarism (refer Figure 1).

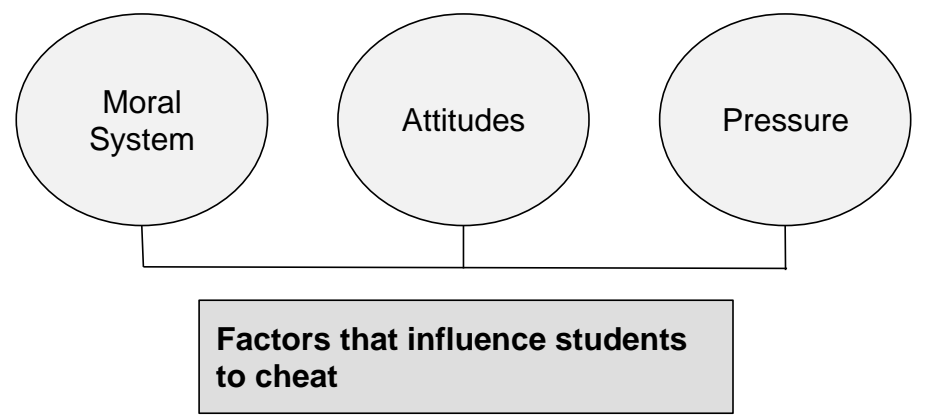

Figure 1

Firstly, students may not necessarily feel plagiarism is a part of their Moral system; it is quite often an imposed value, one without much explanation about its consequences and its long term effect on individual success (Power, 2009). The female student in the story was not exposed to academic integrity as a value with a series of serious consequences. Rather, it was a self-taught concept with a narrow perspective. Hence, a student is influenced to think that it does not really matter if one cheats, as long the short term results are favorable.

The second factor that contributed to the cheating strategy is also the Attitude of the student towards learning itself. If there is a subject that did not appeal to the student due to its difficulty level or a pre-existent mental barrier (physics, in the case above), there was an additional reason to ease the situation at hand by cheating. According to the student, a well-executed plan with a good cheat "strategy" was enough to pass a test. There was no goal increasing proficiency in that subject that could add to the student's existing knowledge base. This highlights the third important factor - Pressure.

In this case, pressure was to score and become a "high net worth" student in order to conform to the society composed of parents, who want their child to be the best and fellow pupils with a passive influence to "fit in" to the groupism game to attain their sense of belongingness.

This model abbreviated as MAP, reveals the basic ground level truth that provides an insight for all educators and parents who need to rethink their approach towards teaching, right from primary school onwards.

A significant lesson for educators and parents can be learned from the teacher in the story. Disciplinary actions require considerable forethought and must change for modern students. Reyna et. al (2001) outlines two types of typical teacher reactions towards students - one being Utilitarian, which focuses on amending thinking and future behavior of students and the other Retributive, which highlights a past wrong and avenges for it.

In this case of the student, the MAP model sees a slight change when the Utilitarian goal was addressed wherein the fear route was not adopted. A direct appeal to the student's moral system by highlighting a long term consequence seems to have had an 
effect in the student's subsequent approach at the university level and the workplace. Table 1 depicts the MAP model across three levels of this student's journey and shows a considerable shift in her approach which was a result of the teacher's approach.

Table 1

MAP model applied to the case study

\begin{tabular}{|l|l|l|l|}
\hline & SCHOOL & UNIVERSITY & WORKPLACE \\
\hline Moral System & $\begin{array}{l}\text { Flawed - with a little or } \\
\text { no understanding of } \\
\text { academic integrity }\end{array}$ & $\begin{array}{l}\text { Renewed thinking, } \\
\text { introduction to } \\
\text { academic integrity }\end{array}$ & $\begin{array}{l}\text { Academic Integrity has } \\
\text { become a way of life }\end{array}$ \\
\hline Attitude & $\begin{array}{l}\text { Short term - pass a test } \\
\text { or exam. Cheating was } \\
\text { okay if not caught by } \\
\text { authority. }\end{array}$ & $\begin{array}{l}\text { Temptation to } \\
\text { outsource assignments } \\
\text { but not acted upon }\end{array}$ & $\begin{array}{l}\text { Integrity was important } \\
\text { to keep company } \\
\text { goodwill }\end{array}$ \\
\hline Pressure & $\begin{array}{l}\text { Scoring of marks and "fit } \\
\text { in" peer groups }\end{array}$ & $\begin{array}{l}\text { Complete complex } \\
\text { assignments on time, } \\
\text { new environment. }\end{array}$ & $\begin{array}{l}\text { Integrity won the war, } \\
\text { efforts recognized. }\end{array}$ \\
\hline
\end{tabular}

While the MAP model has simplified a student's thinking, this model may differ when having a binocular view of other students' journeys who belong to other cultures. Since different cultures have different learning techniques, therefore academic integrity approaches may also vary. The MAP model is a window to the Asian student's journey towards her understanding and maybe applied across institutions to understand any person's academic integrity journey.

\section{Conclusion}

This story brings a stark truth to the forefront - plagiarism and cheating have no starting age group when it comes into action. More often than not, it has crept into the minds of students when they are quite young and has been linked into cognitive behavior. Research shows that preschool children as young as 3 years are susceptible to various cheating practices. Children are capable of devising tactics even before they can reason, which gives another purpose for parents and educators to help students to reason out the consequences of cheating right from childhood (Ding, et al., 2014). If children have the capability of adopting 'cheat' tactics, why can they not be influenced to adopt 'study' tactics that keeps their minds away from cheating? Today, we as research experts that are envisioning the ethical future of tomorrow's leaders also have a greater responsibility to influence student's minds and steer it in the right direction. Educators have adopted and undoubtedly continue to adopt more learning strategies, with every new technology. However, it is imperative to access the student mind as frequently as possible to maneuver our approach as educators. Whether we choose to accept it or not, academic integrity is largely also a personal value that must reach hearts and it is important that we avoid restricting our studies to considering students as groups alone.

Every student's individuality, background, culture and religion may play significant roles in each approach. As researchers of academic integrity, we may need to accept that there may not be one "pill" that solves the "pandemic" called academic dishonesty, just 
like every patient, every student is different and might need a combination of social, psychological, emotional and ethical prescriptions tailored for their needs. As daunting a task as this sounds with billions of students around the world within the responsibility of relatively few teachers and/or parents alone - deriving trends as a result of studying many individual experiences can improvise the MAP model to a broader concept that encompasses future challenges. If one study such as this one can provide noteworthy inferences, one can only imagine how much can be derived from studying different types of students using this methodology and model. Indeed, students may well have the antidote that we researchers may be looking for elsewhere.

\section{References}

Brinkworth, R., McCann, B., Matthews, C., \& Nordström, K. (2009). First year expectations and experiences: Student and teacher perspectives. Higher Education, 58(2), pp. 157-173.

Chao, C. A., Wilhelm, W. J., \& Neureuther, B. D., (2009). A study of electronic detection and pedagogical approaches for reducing plagiarism. The Journal of Research in Business Education, 51(1), p. 31.

Corcoran, P. B., Walker*, K. E., \& Wals, A. E. (2004). Case studies, makeyourcase studies, and case stories: a critique of casestudy methodology in sustainability in higher education. Environmental Education Research, 10(1), pp. 7-21.

Comas-Forgas, R., \& Sureda-Negre, J. (2010). Academic plagiarism: Explanatory factors from students' perspective. Journal of Academic Ethics, 8(3), pp. 217-232.

DAhlstrom, M. F. (2014). Using narratives and storytelling to communicate science with nonexpert audiences. National Academy of Sciences. Proceedings of the National Academic of Sciences of the United States of America. Available URL: https://www. pnas .org/content/111/Supplement_4/13614

Danilyuk, J. (2020). Academic Cheating Statistics: This Is What You Ought To Know. [online] Unicheck Blog for Education Junkies. Available at: https://unicheck.com/blog/academic-cheating-statistics

Ding, X. P., Omrin, D. S., Evans, A. D., Fu, G., Chen, G., \& LeE, K. (2014). Elementary school children's cheating behavior and its cognitive correlates. Journal of experimental child psychology, 121, pp. 85-95.

GALLAGHER, K. M., (2011). In search of a theoretical basis for storytelling in education research: Story as method. International Journal of Research E Method in Education, 34(1), pp. 49-61.

ICAI. (2020). Statistics. [Online] Available URL https://www. academicintegrity.org/statistics/ Accessed 24 May 2020

Jonassen, D. H., \& Hernandez-Serrano, J. (2002). Case-based reasoning and instructional design: Using stories to support problem solving. Educational Technology Research and Development, 50(2), pp. 65-77.

Joy, M., Cosma, G., YAU, J. Y. K., \& Sinclair, J. (2010). Source code plagiarism - a student perspective. IEEE Transactions on Education, 54(1), pp. 125-132.

KendAll, J. E., \& KendALL, K. E. (2012). Storytelling as a qualitative method for IS research: heralding the heroic and echoing the mythic. Australasian Journal of Information Systems, $17(2)$.

Kolb, D. (1981). Learning styles and Disciplinary Differences. [online] Available at: https://learningfromexperience.com/downloads/research-library/ learning-styles-and-disciplinary-differences.pdf

Markwell, J., \& Courtney, S. (2006). Cognitive development and the complexities of the undergraduate learner in the science classroom. Biochemistry and Molecular Biology Education, 34(4), pp. 267-271. 
McCabe, D. L., Butterfield, K. D., \& Treviño, L. K. (2006). Academic dishonesty in graduate business programs: Prevalence, causes, and proposed action. Academy of Management Learning E Education, 5(3), pp. 294-305.

McCabe, D. L., Treviño, L. K., \& Butterfield, K. D. (2001). Cheating in academic institutions: A decade of research. Ethics $\mathcal{E}$ Behavior, 11(3), pp. 219-232.

Munaro, A. C., \& Vieira, A. M. D. P. (2016). Use of Transmedia Storytelling for Teaching Teenagers. Creative Education, 7(07), p. 1007.

PACE, C. R., (1984). Measuring the Quality of College Student Experiences. An Account of the Development and Use of the College Student Experiences Questionnaire.

Perry, W., (1970). Forms Of Intellectual And Ethical Development In The College Years. New York [N.Y.]: Holt, Rinehart and Winston.

Power, L. G., (2009). University students' perceptions of plagiarism. The Journal of Higher Education, $80(6)$, pp. $643-662$.

Reyna, C., \& Weiner, B. (2001). Justice and utility in the classroom: An attributional analysis of the goals of teachers' punishment and intervention strategies. Journal of educational psychology, 93(2), p. 309.

RoONEy, T., LAwLOR, K., \& RoHAN, E. (2016, May). Telling tales: Storytelling as a methodological approach in research. In ECRM2016 - Proceedings of the 15th European Conference on Research Methodology for Business Management: ECRM2016 (p. 225). Academic Conferences and publishing limited.

ROWLEY, J. (2002). Using case studies in research. Management research news.

Solórzano, D. G., \& Yosso, T. J. (2002). Critical race methodology: Counter-storytelling as an analytical framework for education research. Qualitative inquiry, 8(1), pp. 23-44.

Cunsolo Willox, A., Harper, S. L., \& Edge, V. L. (2013). 'My Word': Storytelling and Digital Media Lab and Rigolet Inuit Community Government. Storytelling in a digital age: digital storytelling as an emerging narrative method for preserving and promoting indigenous oral wisdom. Qualitative Research, 13(2), pp. 127-147.

\section{Authors}

Swathi Reza Venugopal, Love That Design, 28 LightBulbs, Knowledge Park, 20183 Dubai, United Arab Emirates, e-mail: swathinithia@gmail.com

Dr Zeenath Reza Khan, University of Wollongong in Dubai, Knowledge Park, 20183

Dubai, United Arab Emirates, e-mail: zeenath.khan@gmail.com 